\title{
Population Projection Using the Implementation of Differential Equation of Logistic Models
}

\author{
Dewi Anggreini ${ }^{1}$, Dian Septi Nur Afifah ${ }^{2}$, Diesty Hayuhantika ${ }^{3}$, Ratri Candra Hastari ${ }^{4}$, \\ Ratih Puspasari ${ }^{5}$ \\ \{dewi.angreini@stkippgritulungagung.ac.id\} \\ STKIP PGRI Tulungagung ${ }^{1,2,3,4,5}$
}

\begin{abstract}
Projections of population have long been an important problem in the world. Population size and growth in a country directly influence the situation of the economy, policy, culture, education and costs of natural resources. This study aims to determine the projected population growth in the East Java local city in Indonesia, named Ponorogo, using logistic growth model based on the growth rate and carrying capacity. The research method used in the first stage is to determine the research subject. The second stage is (a) collecting research data (b) data analysis and finally drawing conclusions. This research is a new way of determining population projections based on growth rate and carrying capacity so that population projection data can be obtained in 2030 . The results of the study show that IV logistics model is more appropriate for predicting the population in Ponorogo Regency for 2030 , which is 889.956 people with a capacity of $912.355,44$ people. The results of this study can be useful as policy makers for the Central Statistics Agency, Civil Registry Service in projecting the number of residents in the future as well.
\end{abstract}

Keywords: Carrying Capacity, Logistic Growth Model, Population Growth, Projection Population.

\section{Introduction}

Ponorogo is a regency which is popular with reog city. Ponorogo had a population of 868,814 inhabitants and the density of a population of 631 inhabitants/km2[1]. The population density is the number of residents per unit area/unit area. Ponorogo has an area of $1,371.78 \mathrm{~km} 2$ with an altitude between 92 up to 2,563 metres above sea level which has divided into 2 sub area, namely the area of Plateau covering Kecamatan Pulung, Sooko, Ngrayun, and Ngebel, the rest is a lowland area. The focus of this research has founded a new way to calculate the carrying capacity, rate of growth and the number of inhabitants, so that the population projection data got may use by the users of the data population and civil registry Department or Central Bureau of Statistics as a consideration of decision-making.

The formulation of this research is how to determine the value of carrying capacity that limits the population in Ponorogo Regency, how to determine the population growth rate, how to calculate the population in Ponorogo Regency in 2030, how to determine the projected population in Ponorogo Regency using a logistical model. Projections of population have long been an important problem in the world. Population size and growth in a country directly influence the situation of the economy, policy, culture, education and costs of natural resources.

By applying logistic model consists of some errors.For the accuracy of prediction we define appropriate error equation which satisfies trend of population growth of china.In this work we 
can minimizing the error in prediction of population of china. Through appropriate higher order error equation and by using logistic model we can predict population of china.It should also be noted that for china to reach its carrying capacity of 2.2 billion,it would take more than a200 years.After all one discussion it is cleared that the logistic model approach incorporated with error equation is good tool in population estimation.[2]

Science has developed rapidly lately, including differential equations. In the development of differential equations can be represented on problems that occur in everyday life. Population growth is one example of the application of differential equations in the field of Biology. In ecology population growth is often referred to as "population dynamics"[3].

In describing the growth process of living things in a population, mathematically, differential equations are used which describe the relationship of dependence between population numbers at successive times. Most models of development and growth of living things follow the rules relating to the forms of non-linear functions, one example of this growth model is the logistic growth model, which is a growth model that takes into account logistical factors in the form of food availability and living space.

The logistic growth model is a growth model that takes into account logistical factors in the form of food availability and living space. In the logistic model assume that at a certain time the population will approach the equilibrium point. At this point, the number of births and deaths is considered the same so the graph is close to constant.

The results of Khakim and Kwardiniya's study showed an accurate logistic growth model to calculate carrying capacity values, population growth rates, population projections from the city of DKI Jakarta and the city of Surabaya[4]. The research results of Lindo Febdian and Efendi describe accurate logistic models to find out the population projection of West Sumatra Province [5]. Research Results of Zuli Nuraeni In this study a population growth model of Maluku Province was made based on data on the population of the Maluku province using exponential and logistical models [6]. Carrying capacity is obtained by trial and error. Furthermore, using the obtained model predicted the population of Maluku province in 2020. Where as in this study the carrying capacity value will be determined based on the logistic equation, population growth rate and population projection in Ponorogo Regency in the year 2030 uses the Excel and Maple programs.

\section{Literature Study}

\subsection{Growth rate}

According to Brauer and Castillo-Chavez, The value of $r$ is called the intrinsic growth rate because the growth rate is in accordance with the rate of growth of per capita achievement if the size of the small population is sufficient to be convincing from a limited source [7]. So is a value that describes the power of growing a population. In this case, it is assumed $r>0$ that is, considering that each population has the potential to breed.

\subsection{Capability Environment (Carrying Capacity)}

The modification of the logistic equation as follows, the rate of growth and the saturation point is considered to be no longer constant but rather as a function of time is $r=r(t)$ and $\mathrm{K}=$ constant. So thus the modified logistic equation has a form $\frac{d N}{d t}=r N\left(1-\frac{N}{K}\right)$, Where $K=\frac{a}{b}$, value $K$ is the limit of growth where the population starts to grow below this value, does not cross but only approaches that value. $K$ is also called the saturation level. So $K$ is the carrying capacity of an area for population and value $r$ termed the intrinsic growth rate is a value that 
describes the growing power of a population. $\mathrm{N}$ use values derived from the value of carrying capacity limit of that is

$$
N_{(t)} \max =\lim _{t \rightarrow \infty} N(t)=\frac{a}{b}=\frac{N_{1}\left(2 N_{0} N_{2}-N_{2} N_{1}-N_{0} N_{1}\right)}{N_{0} N_{2}-N_{1}^{2}}
$$

\subsection{Logistics Growth Model}

According to Tarumingkeng, the logistical equation is prepared based on the assumption that the population will seek balance with the environment so that it has a stable age distribution [3]. A population has a growth rate which gradually according to constant with a constant $r$. Influence $r$ to increase because of growing population density is the instantaneous response or outright and there are no delays or gaps of time (time lag). Throughout the time the growth of environmental conditions has not changed. The effect of density is the same for all age levels of the population. Opportunities for breeding are not affected by density. The logistic model used in this study is

$$
\begin{gathered}
N(t)=\frac{K}{e^{-r t}\left(\frac{K}{N_{0}}-1\right)+1} \text { with } K \text { obtained from } \\
\lim _{t \rightarrow \infty} N(t)=\frac{a}{b}=\frac{N_{1}\left(2 N_{0} N_{2}-N_{2} N_{1}-N_{0} N_{1}\right)}{N_{0} N_{2}-N_{1}{ }^{2}} .
\end{gathered}
$$

\subsection{Function}

\section{Definition $1[8]$}

Known $R$ relation from $A$ to $B$. If every $x \in A$ related $R$ with exactly one $y \in B$ then $R$ called the function of too. So, relations $R$ from $A$ to $B$ called a function if for each $x \in A$ there is exactly one $y \in B$ so that $b=R(a)$. Next, if $f$ is a function of the set A to the set $\mathrm{B}$, then it is written $f: A \rightarrow B$. In this case, the set A called the domain or region of definition or area of origin, while the set $\mathrm{B}$ named codomain or function area $f$.

Definition 2. [8]

A function $f$ is a rule that matches each element $x$ in a set A exactly one element, called $f(x)$, in a set $\mathrm{B}$.

\subsection{Integral}

Definitions 4 [9].

$F$ called a derivative proof $f$ at intervals $I$ if $D_{x} F(x)=f(x)$ on $I$ that is if

$F^{\prime}(x)=f(x)$ for each $x$ in $I$.

Theorem 1 [9].

If $r$ is any rational number except -1 , then

$\int x^{r} d x=\frac{x^{r+1}}{r+1}+C$

Definitions 5 [7].

An indeterminate or antiderivative integral is a reverse operation looking for a derivative function. Strictly speaking, in finding derivative functions, if a function $F$ is known the function can be determined $f$ so: $\frac{d F(x)}{d x}=f(x)$ for each $\in[a, b]$. Conversely, in an indeterminate integral if 
a function $f$ is known on function will be determined $F$ on the hose so $\frac{d F(x)}{d x}=f(x)$ for each. $x \in[a, b]$ This operation is usually written: $\int f(x) d x=F(x)$,

In this case, a function $f$ called the integrand function and function $f$ called primitive functions $f$.

If known $\int f(x) d x=F(x)$ it can also be written $\int f(x) d x=F(x)+C$, with $C$ any real constant because:

$\frac{d(F(x)+C)}{d x}=\frac{d(F(x))}{d x}+\frac{d(C)}{d x}=\frac{d(F(x))}{d x}+0=f(x)$.

Therefore, if $F$ primitive function $f$ then it is generally written:

$\int f(x) d x=F(x)+c$.

\subsection{Differential Equations}

The differential equation is an equation that contains one or more derivatives of an unknown function. A border differential equation can be written in the form of:

$F\left(x, y, y^{\prime}, y^{\prime \prime}, \ldots, y^{(n)}=0\right.$

With $y^{(n)}$ symbolizes the derivative to $n$ from $y$ to $x$. Special cases if $F$ a linear function of $y^{\prime}, y^{\prime \prime}, \ldots, y^{(n)}$ equation can be written as the following form:

Differential Equations which can be written in a form

$a_{0}(x) y^{(n)}+a_{1}(x) y^{(n-1)}+\cdots+a_{n}(x) y=F(x)$,

With $a_{0}, a_{1}, \ldots, a_{n}$ and $F$ functions of $x$ only and $a_{0}(x) \neq 0$ called linear order $n$ differential equations. The equation is linear in $\boldsymbol{y}^{\prime}, \boldsymbol{y}^{\prime \prime}, \ldots, \boldsymbol{y}^{(\boldsymbol{n})}$.

\subsection{First Order Linear Differential Equations}

Differential equations with shapes $\frac{d y}{d x}+P y=Q$ [9], with $P$ and $Q$ is a function $x$ only, called the First Order Differential equation. An equation of this type in principle can always be solved. First, multiply the two segments by integral factors.

S. $S=e^{\int p(x) d x}$, which produce

$$
e^{\int p(x) d(x)} \frac{d y}{d x}+e^{\int p(x) d x} P(x) y=Q(x) e^{\int p(x) d x} .
$$

Then identify the left side as the derivative of $y e^{\int p(x) d x}$, so the equation forms $\frac{d}{d x}\left(y e^{\int p(x) d x}\right)=Q(x) e^{\int p(x) d x}$

Integration of the two generating sections. $y e^{\int p(x) d x}$ So that, $\frac{d}{d x}\left(y e^{\int p(x) d x}\right)=Q(x) e^{\int p(x) d x}$ 


\section{Research Method}

This study used a descriptive method with qualitative approaches. This study is a descriptive study with a qualitative approach $\mathrm{f}$ intended to apply a differential equation model of population growth in the population in Ponorogo especially logistic population model. This study uses secondary data collection from several sources to be processed. The research method used in this study is: The first stage is to determine the subject of research, while the subject of the study was the number of people starting in 2010 until the year 2016 in Ponorogo and the Second Stage is (1) collecting research data, while the research data collection is obtained from secondary data in the Ponorogo Regency Central Bureau of Statistics (2) data analysis and finally draw conclusions. The location of this research is Ponorogo Regency Central Bureau of Statistics (BPS).

\subsection{Model used}

In the logistic growth model uses the rules of logistics (logistic law) that the logistic supply limits. According to Huberman [10], This model assumes that at certain times the population will approach equilibrium. At this point, the number of births and deaths is considered the same, so the graph will be near constant (zero growth). Zero population is certainly an equilibrium population. However, the major interest is in the case in which $\mathrm{N}=\mathrm{a} / \mathrm{b}$. This is the largest population which the environment can sustain without loss, the so-called carrying capacity of the environment. From these assumptions, a population growth model was derived which was called the logistic growth model, namely:

$$
\frac{1}{N} \frac{d N}{d t}=r-\frac{r}{K} N \text { or } \frac{d N}{d t}=r N\left(1-\frac{N}{K}\right)
$$

\subsection{Data collection technique}

The data used in this study there is only one type, namely secondary data. Secondary data were collected from several sources, including data of the population was taken from the Central Statistics Agency (BPS) Ponorogo district from 2010 until the year 2016.

\subsection{Data Analysis Techniques}

The techniques used in analyzing the form and model of this study are as follows: a) M constructing models of differential equations Verhulst / logistics, b) find a solution of differential equations $\frac{d N}{d t}=r N\left(1-\frac{N}{K}\right)$. c). The time taken is measured and the initial number of population and population in the following year are assumed when $t=0$, that is $\mathrm{N}_{0}$ when $\mathrm{t}=1$ which is $\mathrm{N}_{1}$ and when $\mathrm{t}=2$ which is $\mathrm{N}_{2}$. d). determine to carrying capacity. e) Look for population growth rates, namely $r$ using the solution of the logistic equation model.

a) Summing the population in Ponorogo Regency with a logistical equation solution.

b) Determining the projected population in Ponorogo Regency uses a logistic growth model whose value is close to the census results. 


\section{Results And Discussion}

\subsection{Logistics Growth Model}

The logistic model assumes that at certain times the number of population will approach an equilibrium point (equilibrium). At this point, the number of births and deaths is considered the same so the graph is close to constant. The simplest form for the relative growth rate that accommodates these assumptions is:

$\frac{1}{N} \frac{d N}{d t}=k\left(1-\frac{N}{K}\right)$

Multiply by $N$, the model is obtained for known population growth

\subsection{Logistical differential equation}

$$
\frac{d N}{d t}=r N\left(1-\frac{N}{K}\right)
$$

Notice from equation (2) that if $N$ is small compared to $K$, then $N / K$ close to 0 and $d N / d t \approx$ $r N$. However, if $N \rightarrow K$ (population approaches capacity), then $N / K \rightarrow 1$, so $\frac{d N}{d t} \rightarrow 1$. If population $N$ is between 0 and $\mathrm{K}$, then the right segment of the equation above is positive, so $\frac{d N}{d t} \rightarrow 1$ and population rises. But if the population exceeds its capacity $(\mathrm{N}>\mathrm{K})$, then $1-\frac{N}{K}$ negative, so $\frac{d N}{d t}<$ 0 and the population goes down.

$N=\frac{K e^{r t+c}}{1+e^{r t+c}}$

From equation (3) if we give the initial value $\mathrm{t}=0$ and $N(0)=\mathrm{N}_{0}$, then substitute it into (3) then the value $c=\ln \left(N_{0} / K-N_{0}\right)$ will be obtained then $c$ value is substituted again in equation (3) so that a special solution is obtained from the logistics model as follows,

$N=\frac{K}{e^{-r t}\left(\frac{K}{N_{0}}-1\right)+1}$

\subsection{Formulation Model}

The population growth rate that continues to increase can be minimized by the presence of inhibiting factors. The logistic growth model is a growth model that is limited by an inhibiting factor. Derived the equation model as follows:

$\frac{d N(t)}{d t}=a N(t)\left(1-\frac{N(t)}{M}\right)$

If $M=a / b$ then obtained 
$\frac{d N(t)}{d t}=a N(t)-b N^{2}(t)$

$\frac{1}{a}(\ln N(t)-\ln (a-b N(t)))=t+C$

If given conditions $t=0$ so $N(0)=N_{0}$ obtained $C=\frac{1}{a}\left(\ln N_{0}-\ln \left(a-b N_{0}\right)\right)$ Therefore equation (6) becomes

$\frac{1}{a}(\ln N(t)-\ln (a-b N(t)))=t+\frac{1}{a}\left(\ln N_{0}-\ln \left(a-b N_{0}\right)\right)$

Obtained value as follows

$N(t)=\frac{a / b}{1+\left(\frac{a / b}{N_{0}}-1\right) e^{-a t}}$

Suppose at the moment $t=1$ and $t=2$ from equation (8) is obtained

$N_{1}=\frac{b}{a}\left(1-e^{-a}\right)=\frac{1}{N_{1}}-\frac{e^{-a}}{N_{0}}$ and

$N_{2}=\frac{b}{a}\left(1-e^{-2 a}\right)=\frac{1}{N_{2}}-\frac{e^{-2 a}}{N_{0}}$

From equation (9) is obtained

$\left(1+e^{-a}\right)=\frac{\frac{1}{N_{2}}-\frac{e^{-2 a}}{N_{o}}}{\frac{1}{N_{1}}-\frac{e^{-a}}{N_{0}}}$

So that $e^{-a}=\frac{N_{o}\left(N_{1}-N_{2}\right)}{N_{2}\left(N_{0}-N_{1}\right)}$,

Equation (11) is substituted in equation (9) so that it is obtained

$\frac{b}{a}=\frac{N_{o} N_{2}-N_{1}^{2}}{N_{1}\left(2 N_{0} N_{2}-N_{2} N_{1}-N_{0} N_{1}\right)}$

Thus the value of $\mathrm{K}$ or carrying capacity is obtained from the limit value of $N(t)$ is

$N(t)_{\max }=\lim _{t \rightarrow \infty} N(t)=\frac{a}{b}=\frac{N_{1}\left(2 N_{0} N_{2}-N_{2} N_{1}-N_{0} N_{1}\right)}{N_{0} N_{2}-N_{1}^{2}}$

\subsection{Data on Population in Ponorogo Regency}

In this study, data on the number of people used the data of population census results in Ponorogo from the year 2010 until the year 2016 sourced from the Central Statistics Agency (BPS) in Ponorogo. The following is table 1 which states the population in Ponorogo district from 2010-2016: 
Table 1. Data on Population Numbers Ponorogo Regency

\begin{tabular}{cc}
\hline Year & Population Numbers \\
\hline 2010 & 856.682 \\
2011 & 859.302 \\
2012 & 861.806 \\
2013 & 863.890 \\
2014 & 865.809 \\
2015 & 867.393 \\
2016 & 868.814 \\
\hline
\end{tabular}

\subsection{Completion of the Population Growth Logistics Model Ponorogo Regency}

To determine the logistic model from the population data in Ponorogo Regency in table 1 above, it was previously assumed that time $(t)$ measured in years and suppose $t=0$ in 2010 then the initial requirement is $\mathrm{N}(0)=856.682$.

Next is to determine the carrying capacity value that is

$\mathrm{K}=$ that is $N(t)_{\text {Max }}=\lim _{t \rightarrow \infty} N(t)=\frac{a}{b}=\frac{N_{1}\left(2 N_{0} N_{2}-N_{2} N_{1}-N_{0} N_{1}\right)}{N_{0} N_{2}-N_{1}{ }^{2}}$

From table 1 obtained $\mathrm{t}=0,1,2$ in 2010, 2011, 2012 with values each is

$N_{0}=856.682$

$N_{1}=859.302$,

$N_{2}=861.806$

Value $N_{0}, N_{1}, N_{2}$ substituted together to find the value of carrying capacity to obtain a value that limits the population in Ponorogo Regency, East Java Province, namely

$N(t)=\frac{a}{b}$

Then the calculation is as follows:

$N(t)_{\max }=\lim _{t \rightarrow \infty} N(t)=\frac{a}{b}=\frac{N_{1}\left(2 N_{0} N_{2}-N_{2} N_{1}-N_{0} N_{1}\right)}{N_{0} N_{2}-N_{1}^{2}}$

By substituting $N_{0}, N_{1}, N_{2}$ to formula (13) result value $\mathrm{K}=912,355.44$.

Value $K$ and $N_{0}$ distributed to the logistics model solution (14) so that it is obtained $N=\frac{K}{e^{-r t}\left(\frac{k}{N_{0}}-1\right)+1}$,

$N=\frac{912.365,44}{e^{-r t}\left(\frac{912.365,44}{856.682}-1\right)+1}$,

$N=\frac{912.365,44}{e^{-r t}(0,064999)+1}$, 
Furthermore, from the equation (14) a logistic model will be found that can represent the rate of population growth in Ponorogo Regency for $t=1$ in 2010 then $N(1)=859.302$ if distributed to equations (14) is obtained,

$$
\begin{aligned}
& 859.302=\frac{912.365,44}{e^{-r}(0,06499)+1}, \\
& e^{-r}(0,064999)=\frac{912.365,44-859.302}{859.302}, \\
& e^{-r}(0,06499)=0,06175 \\
& e^{-r}=\frac{0,06175}{0,06499}=0,95004, \\
& -r=\ln (0,95004) \\
& -r=-0,05124 \\
& r=0,05124
\end{aligned}
$$

A value obtained is redistributed to (14) then produces

$N=\frac{912.365,44}{(0,06499) e^{-(0,05124) t}+1}, \quad \quad$ (Model I)

For $t=2$ in 2012 then $N(2)=861.806$ if substituted to equation (14) is obtained $r=$ 0,051245

If a value $r$ obtained is substituted return p exists (14 ) then produces

$N=\frac{912.365,44}{(0,06499) e^{-(0,051248) t}+1} \quad($ Model II $)$

For $t=3$ in 2013 then ( 3$)=863.890$, if substituted to equation (14) is obtained $r=0,049001$

If a value $r$ obtained is substituted again at (14) then proceed

$N=\frac{912.365,44}{(0,06499) e^{-(0,04900) t}+1} \quad$ (Model III)

For $t=4$ in 2014 then $N(4)=865.809$, if substituted into equation (14) is obtained $r=$ 0,04740

If a value $r$ obtained is substituted again at (14) then proceed

$$
N=\frac{912.365,44}{(0,06499) e^{-(0,04740) t}+1} \quad(\text { Model IV })
$$

for $t=5$,in 2015 then $N(5)=867.393$, if substituted into equation (14) is obtained $r=$ 0,04521

If a value $r$ obtained is substituted again at (14) then produces 
$N=\frac{912.365,44}{(0,06499) e^{-(0,04521) t}+1}$

(Model V)

for $t=6$, in 2016 then $N(6)=868.814$, if substituted into the equation (14) obtained $r=$ 0,04327

If a value $r$ obtained is substituted again at (14) then yields

$N=\frac{912.365,44}{(0,06499) e^{-(0,04327) t}+1} \quad$ (Model VI)

From the results of the calculation above, the logistical model results are obtained as follows:

1. Logistics Model I, the form of the equation

$$
N=\frac{912.365,44}{(0,06499) e^{-(0,05124) t}+1}
$$

with relative growth rate per year is $5.1 \%$

2. Logistics Model II, the form of the equation $N=\frac{912.365,44}{(0,06499) e^{-(0,05125) t}+1}$

with the relative growth rate per know, $\mathrm{n}$ is $5.1 \%$

3. Logistics Model III, the form of the equation $N=\frac{912.365,44}{(0,06499) e^{-(0,049001) t}+1}$

with the relative growth rate per year is $4.9 \%$

4. Logistics Model IV, the form of the equation $N=\frac{912.365,44}{(0,06499) e^{-(0,04740) t}+1}$

with the relative growth rate per know, $\mathrm{n}$ is $4,7 \%$

5. Logistics Model V, the form of the equation $N=\frac{912.365,44}{(0,06499) e^{-(0,04521) t}+1}$

with its relative growth rate per known is $4.5 \%$.

6. Logistics Model VI, the form of the equation

with relative growth rate per year is $4,3 \%$.

$$
N=\frac{912.365,44}{(0,06499) e^{-(0,04327) t}+1}
$$

Based on the calculation by applying the logistical model I to the logistical model VI, the population in Ponorogo district in 2010-2016 was obtained. Then the results of the model calculations are compared with the calculation of the results of the population census from The Central Bureau of Statistics. 
Table 2. Comparison of population amount between census results and model results

\begin{tabular}{cccccccc}
\hline Year & $\begin{array}{c}\text { Census } \\
\text { Result }\end{array}$ & Model 1 & Model 2 & Model 3 & Model 4 & Model 5 & Model 6 \\
\hline 2010 & 856.682 & 856.689 & 856.681 & 856.689 & 856.681 & 856.681 & 856.689 \\
2011 & 859.302 & 859.312 & 859.312 & 859.197 & 859.117 & 859.012 & 859.312 \\
2012 & 861.806 & 861.812 & 861.812 & 861.600 & 861.445 & 861.234 & 861.812 \\
2013 & 863.890 & 864.203 & 864.203 & 863.892 & 863.671 & 863.369 & 864.203 \\
2014 & 865.809 & 866.485 & 866.493 & 866.098 & 865.811 & 865.425 & 866.485 \\
2015 & 867.393 & 868.671 & 868.671 & 868.200 & 867.862 & 867.399 & 868.671 \\
2016 & 868.814 & 870.752 & 870.752 & 870.212 & 869.831 & 869.292 & 870.752 \\
\hline
\end{tabular}

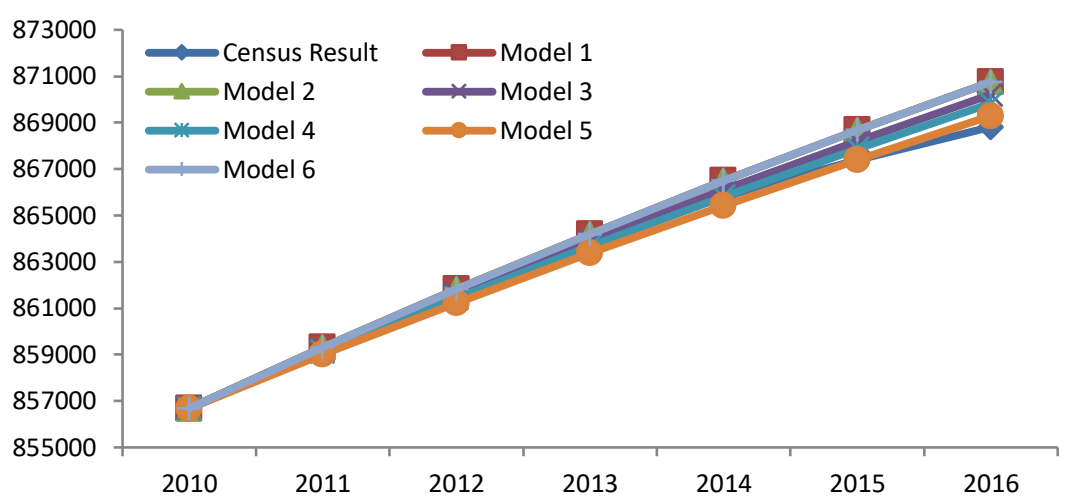

Fig.1 Comparison of population amount between census results and model results

The logistical model IV gives results that are close enough to the census results. Besides the accuracy of the, IV logistical model is quite good, this can be seen from the results of the population in Ponorogo Regency in 2010-201 6 which produced the I V logistical model almost the same as the 2010-201 population census 6. Thus I logistic model IV was chosen as the final model that will be used to predict the population in Ponorogo Regency in the population census 2030 .

\subsection{Prediction of Population in Ponorogo Regency Year 2030}

Because the IV logistics model is used to predict the number of residents in the Regency Ponorogo in the year 2030, then the model equation is:

$N=\frac{912.365,44}{(0,06499) e^{-(0,04740) t}+1}$

Furthermore, to predict the number of population in 2030 taken $t=20$ substituted into the logistical model 1 above obtain: 
$N=\frac{912.365,44}{1,02518}=889.956$

The number of people in Ponorogo in 2030 resulting logistic model is 889.956 .

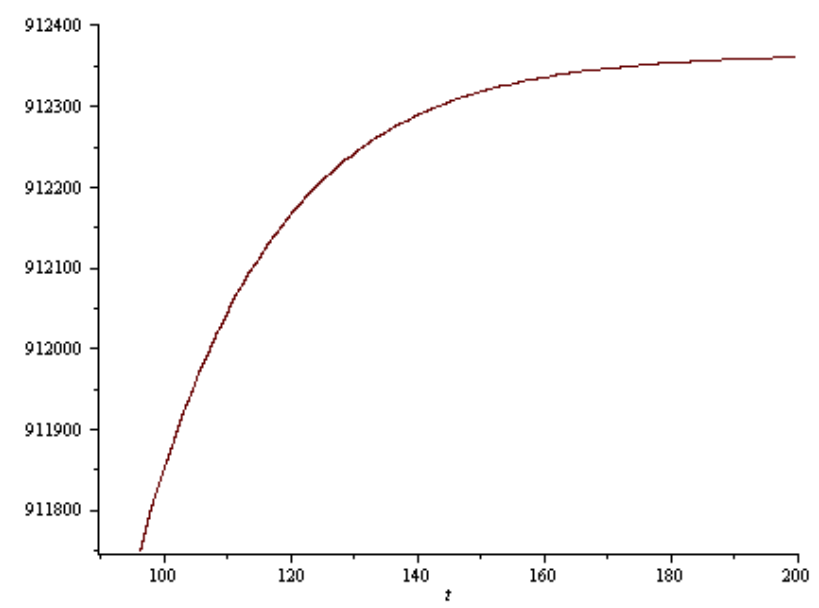

Fig.2 Prediction of Population in Ponorogo Regency Year 2030

\section{Conclusion}

Based on the Maple chart, the population in Ponorogo Regency in the future will not exceed the carrying capacity, but it will approach the carrying capacity value. The carrying capacity value is $912.355,44$. The population growth rate in Ponorogo Regency is 0.04740 . The population in Ponorogo Regency in 2030 is 889.956 people. Projections of the population in Ponorogo Regency are more appropriate to use the IV logistical model because the value is close to the census results with the equation are:

$N=\frac{912.365,44}{(0,06499) e^{-(0,04740) t}+1}$.

\section{Reference}

[1] BPS-Statistics, Katalog BPS: 2101018. Jakarta: Badan Pusat Statistik, Jakarta, 2017.

[2] M. B. Patel, Ajay J. Prajapati, "Estimation for Future Population Growth of China by using Logistic model," Int. J. Sci. Dev. Res., vol. 1, no. 9, pp. 52-56, 2016.

[3] R. C. Tarumingkeng, Dinamika Populasi Kajian Ekologi Kuantitatif. Jakarta: Pustaka Sinar Harapan, 1994.

[4] A. Kwardiniya, J. Matematika, and U. Brawijaya, "Proyeksi Penduduk Provinsi DKI Jakarta dan Kota Surabaya dengan Model Pertumbuhan Logistik,” no. 7, pp. 232-235, 2011.

[5] L. F. dan Efendi, "Menentukan Model Pertumbuhan Penduduk," J. Mat. Univ. Andalas, vol. 2 , no. 4, pp. 54-58.

[6] Z. Nuraeni, "Aplikasi Persamaan Diferensial Dalam Estimasi Jumlah Populasi," Ilm. 
Pendidik. Mat., vol. 5, no. 1, pp. 9-16, 2017.

[7] A. Hastings, " Mathematical Models in Population Biology and Epidemiology . Texts in Applied Mathematics, Volume 40 . By Fred Brauer and, Carlos Castillo-Chávez. New York: Springer . \$59.95. xxiii + 416 p; ill.; index. ISBN: 0-387-98902-1. 2001. ,"Q. Rev. Biol., 2003.

[8] Supama, Kalkulus 1. Yogyakarta: Fakultas Matematika dan IPA, Universitas Gadjah Mada, 2003.

[9] D. Varberg and E. J. Purcell, Kalkulus Jilid 1 Edisi Tujuh. Batam: Interaksara, 2001.

[10] R. Huberman, Mathematical Models Mechanical Vibrations, Population Dynamics and Traffic Flow (An Introduction To Applied Mathematics). New Jersey: Prentice Hall, Inc, 1994. 